\title{
Occurrence of Cryptosporidium spp. oocytes in artificial beaches of Itaipu Lake, Paraná, Brazil
}

\section{Ocorrência de oocistos de Cryptosporidium spp. em praias artificiais do Lago Itaipu, Paraná, Brasil}

\author{
Alessandra Snak ${ }^{*}$; Pedro Rodrigo Hillesheim Soares ${ }^{2}$; Erton Gomes da Silva ${ }^{3}$; \\ Mallú Jagnow Sereno; ; Felipe Gustavo Garcia \\ Marcia Benedita de Oliveira Silva; ${ }^{5}$ Silvia Cristina Osaki ${ }^{6}$
}

\begin{abstract}
Cryptosporidiosis is an emerging zoonosis that causes many outbreaks worldwide. Its main route of transmission is the consumption of contaminated water or food. In Brazil, data on to the occurrence of cryptosporidiosis in animals and in humans are scarce; thus, it is important to determine the occurrence of Cryptosporidium sp. and to identify possible sources of water and food contamination in order to prevent the disease and, consequently, preserve of human health. From July/2011 to March/2012, five liters of water were collected in 10 different locations from eight artificial beaches of Itaipu Lake, Paraná, in a total of 40 samples. In two other small beaches of the lake, water was also collected from two different sites of each beach, given their size and because they were made up of water from different sources. Samples were analyzed by the modified Ziehl-Neelsen technique and nestedPCR (nPCR). All samples were negative in the modified Ziehl-Neelsen; only one (2.25\%) sample was positive in $\mathrm{nPCR}$. These results indicate that PCR is a more sensitive technique for the identification of Cryptosporidium in water samples. In this study, it was not possible to identify the species involved and, thus, the source of infection. Water contamination by Cryptosporidium oocytes can be caused by livestock kept near waterways, and by the people who use the place for recreational purposes. These results demonstrate risk for people who use the lake. Care should be determined to prevent the transmission of this important zoonosis.
\end{abstract}

Key words: Cryptosporidium. PCR. Water. Ziehl-Neelsen.

\section{Resumo}

A criptosporidiose é uma zoonose emergente responsável por vários surtos no mundo todo. Sua principal via de transmissão ocorre pelo consumo de água ou alimentos contaminados. Os dados de ocorrência de criptosporidiose tanto em animais como em seres humanos no Brasil são bastante escassos, dessa forma, torna-se importante a pesquisa da ocorrência de oocistos de Cryptosporidium sp. e a identificação de possíveis fontes de contaminação, visando a prevenção da contaminação da água e consequente preservação da saúde humana. Durante o período de jul/2011 a mar/2012 foram coletados

\footnotetext{
${ }^{1}$ Discente, Curso de Doutorado do Programa de Pós-Graduação em Ciência Animal, Universidade do Estado de Santa Catarina, UDESC, Lages, SC, Brasil. E-mail: alessandra.snak@hotmail.com

2 Médico Veterinário, Clínica Veterinária S.O.S. Pet, S.O.S. Pet, Toledo, PR, Brasil. E-mail: mvpedrosoares@gmail.com

${ }^{3}$ Discentes, Curso de Mestrado do Programa de Pós-Graduação em Ciência Animal, Universidade Federal do Paraná, UFPR, Palotina, PR, Brasil. E-mail:erton_gomes@hotmail.com; mallusereno@gmail.com

${ }^{4}$ Discente, Curso de Graduação em Medicina Veterinária, UFPR, Palotina, PR, Brasil. E-mail: felipedo402@gmail.com

${ }^{5}$ Prof ${ }^{a}$, Universidade Federal do Triângulo Mineiro, UFTM, Uberaba, MG, Brasil. E-mail: mbosilva@yahoo.com.br

${ }^{6}$ Prof $^{\mathrm{a}}$, UFPR, Palotina, PR, Brasil. E-mail: silvia_cristinao@yahoo.com.br

${ }^{*}$ Author for correspondence
} 
cinco litros de água em 10 pontos de oito praias artificiais do Lago da Itaipu, Paraná, resultando em 40 amostras. Em duas prainhas foram coletadas água em dois locais devido ao tamanho das mesmas e por apresentarem fontes de água diferentes. As amostras foram analisadas pelo método de Ziehl-Neelsen modificado e nested-PCR. Das 40 amostras analisadas, todas foram negativas no método de ZiehlNeelsen modificado e uma (1) apresentou fragmento de 819-825 bp (2,25\%) na técnica de nPCR, o que sugere que a PCR é uma técnica mais sensível para a pesquisa de Cryptosporidium em água. No presente trabalho não foi possível identificar a espécie envolvida, e dessa forma a fonte de infecção, ou espécie responsável pela contaminação da água não foi conhecida. A contaminação da água por oocistos de Cryptosporidium pode ser decorrente da criação animal nas proximidades dos cursos d'água e também pelas próprias pessoas que frequentam e utilizam o local. Esses resultados demonstram um risco para as pessoas que frequentam o local, devendo haver uma orientação quanto aos cuidados para evitar a transmissão dessa importante zoonose.

Palavras-chave: Água. Cryptosporidium. PCR. Ziehl-Neelsen.

Several species of the Cryptosporidium spp. parasite humans, as well as domestic and wild animals (FAYER, 2010; PEREIRA et al., 2010; SANTÍN, 2013; SAVIOLI et al., 2006). Some Cryptosporidium spp. are human species-specific and others have zoonotic potential, i.e., they can infect a wide range of hosts, including humans (FENG, 2010).

Cryptosporidium spp. is a parasite belonging to the phylum Apicomplexa that inhabit the microvilli of the gastrointestinal epithelium of mammals and birds. They have been initially known as pathogens of young animals (calves, lambs, and piglets); now they are on the list of neglected diseases as important agents of enterocolitis, diarrhea, and cholangiopathy in humans (XIAO et al., 2004).

Currently, there are about 26 accepted species of Cryptosporidium spp. (ICZN), and 40 described genotypes infecting humans and/or animals (RYAN et al., 2014). However, approximately $90 \%$ of the cases of human cryptosporidiosis are caused by two species, C. hominis and C. parvum (XIAO; RYAN, 2004). According to Ryan et al. (2014), seventeen (17) species of Cryptosporidium have been described in humans. However, those that affect domestic and wild animals can also affect humans, such as C. meleagridis, C. canis, C. felis, and C. fayeri (WALDRON et al., 2010).

Human cryptosporidiosis cases have two routes of oral-fecal transmission, including direct contact with infected people (anthroponotic transmission) or animals (zoonotic transmission), and consumption of contaminated food or water, which are considered the main routes of transmission of Cryptosporidium in endemic areas (XIAO et al., 2004). Cryptosporidium oocysts are resistant to adverse conditions found in the environment and contaminate soil, food and, particularly, water. Infected animals act as a source of infection for humans by releasing oocysts that contaminate water used for human consumption or recreation (DURANTI et al, 2009; SHI et al., 2010). Infected animals act as sources of infection for humans by releasing oocysts that are resistant in water (DURANTI et al., 2009; SHI et al., 2010).

The occurrence of Cryptosporidium spp. in supply and recreational water is a problem that is increasing worldwide (FAYER, 2010; PLUTZER et al., 2008). The parasite can cause watery diarrhea with abdominal cramps, nausea, headache, and anorexia. The infection is especially severe in immunocompromised individuals, such as HIVpositive patients undergoing chemotherapy, organ transplantation patients, and children (ABRAHAMSEN et al., 2004; ARROWOOD; STERLING, 1989; LALLO; BONDAN, 2006).

In December 2010, an outbreak of cryptosporidiosis was recorded in swimmers who went to a recreational park in the Niagara region in Canada. About 12 people showed clinical signs and were diagnosed with Cryptosporidium spp. (HOPKINS et al., 2013). 
Xiao et al. (2013), collected and analyzed water samples of the Three Gorges Reservoir in China, the largest lake in the world, and found positive results for Cryptosporidium spp. and Giardia spp., demonstrating the public health risk posed by these waters.

The micro-regions of Toledo and Foz do Iguaçu, which belong to the west of the Paraná macroregion, concentrate a large number of touristic shores in Itaipu Lake used for recreation. Therefore, the objectives of this study were to determine the occurrence of Cryptosporidium spp. and to identify the possible sources of infection of the water from Itaipu Lake in Paraná, Brazil.

From July/2011 to March/2012, four collections of water were performed in about three months. Five liters of water were collected from ten locations in eight artificial beaches used for recreation in western Paraná, located in the following cities: Missal, Santa Helena, Entre Rios do Oeste, Itaipulândia, São Miguel do Iguaçu, Porto Mendes, Santa Terezinha de Itaipu, and Foz do Iguaçu. In two small beaches (São Miguel do Iguaçu and Santa Helena), two different sample collections were performed due to the size of the beaches and to the fact that they were made up by different sources of water. Therefore, in the study, a total of 40 samples of water were collected.

Untreated water samples were initially concentrated using $\mathrm{NaCl}$ (density $1.15 \mathrm{gmL}^{-1}$ ), according to MACHADO et al. (2006), in order to remove larger particles. Samples were then filtered. After that, $5 \mathrm{~mL}$ of sample were mixed with $5 \mathrm{ml}$ of $\mathrm{NaCl}$ solution, and centrifuged at $206 \mathrm{x} g$ for 10 minutes. The sediment was separated for further analysis using Ziehl-Neelsen stain and NestedPCR (nPCR). The supernatant was filtered through a cellulose membrane with 47-mm long and 0.7$\mu \mathrm{m}$ diameter pores, under 10 to $15 \mathrm{cmHg}$ negative pressure. After that, the membrane was removed, placed in a plastic bag containing PBST, and then rubbed in the package. The eluate was centrifuged at $660 \mathrm{~g}$ for 10 minutes.
The pellet obtained was divided in two parts. One was used for slides stained by modified ZiehlNeelsen (ORTOLANI, 2000), and the other was suspended in $2 \mathrm{ml}$ of lysis buffer (ChargeSwitch ${ }^{\circledR}$ gDNA Mini Tissue Kit) for DNA extraction, and was kept frozen until the DNA extraction process.

The modified Ziehl-Neelsen technique was based on the following steps: 1) smear fixation with $96 \%$ methanol for five minutes; 2) drying at room temperature; 3) staining with carbol-fuchsine for 20 minutes; 4) washing in running water to remove excess dye; 5) bleaching with sulfuric acid solution (H2SO4) $2.5 \%$ for 30 seconds; 6) counterstaining with malachite green for 10 minutes;7) washing in running water to remove excess dye; and 8) drying at room temperature. Slides were examined under a light microscope at 1,000 times magnification, using the immersion objective.

As for nPCR technique, first it was performed with 15 cycles of freezing and thawing for the wall of the oocyst to be broken (OSAKI et al., 2013), following by DNA extraction using the commercial kit ChargeSwitch ${ }^{\circledR}$ gDNA Mini Tissue Kit (Invitrogen).

PCR was performed with the primers XIAF / XIAR (5'TTCTAGAGCTAATACATGCG / 5'CCCATTTCCTTCGA AACAGGA3'), which amplify the hypervariable region of the rRNA gene 18SSU (XIAO et al., 1999). The reaction was performed in a final volume of $25 \mu \mathrm{L}$ containing $3.0 \mathrm{mM} \mathrm{MgCl}_{2}, 200 \mu \mathrm{M}$ of each dNTP, $0.8 \mu \mathrm{M}$ primer, 1.25U Taq DNA polymerase, $5 \mu \mathrm{L}$ DNA. An initial denaturation step was carried out at $94{ }^{\circ} \mathrm{C}-$ $3 \mathrm{~min}$, followed by 35 cycles at $94^{\circ} \mathrm{C}-45 \mathrm{~s} / 55$ ${ }^{\circ} \mathrm{C}-1 \mathrm{~min} / 72^{\circ} \mathrm{C}-1 \mathrm{~min}$, and final extension at $72^{\circ} \mathrm{C}-7 \mathrm{~min}$. The products were submitted to nested PCR, using the primers XIA1F and XIA2R (5'GGAAGGGTTGTATTTATTAGATAAAG3' / 5'AAGGAGTAAGGAACAACCTCCA) under the same conditions described above. A sample from the feces of a calf that was previously infected with Cryptosporidium spp. served as the positive control; 
autoclaved milli-Q water was used as the negative control. The products amplified by nPCR were separated by electrophoresis in agarose gel 1.6\%.

All samples were negative in the modified ZiehlNeelsen method. However, in the nPCR technique, one sample contained an 819-825bp fragment compatible with Cryptosporidium spp., resulting in $2.5 \%(1: 40)$ positive results in Western Paraná recreational beaches. The positive sample was from Itaipulândia little beach, collected in September and only in the filter membrane, the sediment of the sample negative.

The PCR assay was more sensitive than the modified Ziehl-Neelsen method, corroborating the findings of Banjo et al. (2013), El-Shazly et al. (2002), Kar et al. (2011), Masood et al. (2013), Morgan et al. (1998), Paul et al. (2009), and Tahvildar-Biderouni and Salehi (2014), who found greater sensitivity and specificity using PCR in the diagnosis of Cryptosporidium spp..

More frequent positive results than those described in our study were reported by Betancourt et al. (2014) who collected water samples from 26 recreational beaches in the central coast of Venezuela, finding 14\% (5:26) of samples positive for Cryptosporidium spp. Galván et al. (2014), in central Spain, analyzed 150 samples from wastewater treatment plants and freshwater beaches used for recreation, and found $26.7 \%$ positive samples for this protozoa: $50.8 \%$ positive samples in industrial wastewater, and $17.5 \%$ in freshwater beaches. These results demonstrate the high level of fecal contamination in recreational waters.

Other studies have shown frequencies higher than those found in the present study. On the beaches of southern Europe (Portugal), 82\% (60:74) of the water samples were positive for Cryptosporidium. In these samples Giardia spp. and thermotolerant fecal coliforms were also found (JÚLIO et al., 2012).

In Brazil, there are no reports on Cryptosporidium spp. in recreational waters, but many studies have identified oocysts of the parasite in water sources used for human consumption (ARAÚJO et al., 2011; BASTOS et al., 2004; CARDOSO et al., 2003; CORTES et al., 2014; SANTOS et al., 2004). Almeida et al. (2015) analyzed samples of untreated water and found $8.33 \%$ positive samples for Cryptosporidium sp. in the city of Londrina, Paraná. In the present study, it was not possible to identify the species involved in the contamination; thus, the source of infection or the species responsible for water contamination is not known.

Contamination of water by Cryptosporidium oocytes can be caused by livestock kept near the waterways and by people who use the place, as well. The routine use of recreational waters by people who have bowel incontinence, and especially by children with diarrhea, facilitated and enhanced the transmission of cryptosporidiosis (FAYER et al., 2000). Loganthan et al. (2012) compared the results for the presence Cryptosporidium in an area used for recreation and another area that was not used for this purpose in a hydrographic basin in southwester Australia and found that recreational water catchments showed higher prevalence of Cryptosporidium. Furthermore, results revealed that the occurrence of the parasite in recreational areas was a much higher. These waters were considered to pose a very high risk to public health and should not be used for human consumption.

At the "Chaharmahal va Bakhtiyari" water park in the Province of Iran, 30 water samples were collected, and six (20\%) of theme were positive for Cryptosporidium spp. In this area, cattle were considered the main source of water contamination (MANOUCHEHRI NAEINI et al., 2011). Xiao et al. (2013), collected and analyzed water samples of the "Three Gorges Reservoir" in Chine, the largest lake worldwide, and found positive results for Cryptosporidium spp. and Giardia spp., demonstrating the public health risk of these waters.

Several outbreaks were reported worldwide, especially in countries where there is greater control 
and reporting (FAYER et al., 2000; HLAVSA et al., 2014). In Brazil, data are scarce, demonstrating the importance of conducting studies, such as the present one, to identify and control contamination in water used either for human and animal consumption, or for recreation.

From 1986 to 1998, cryptosporidiosis outbreaks associated with recreational waters involved more than 10,000 people in several countries, including the UK, USA, Australia, Canada, and New Zealand (FAYER et al., 2000). In the US, in 2009 and 2010, from 57 outbreaks of disease related to recreational waters, 24 (42\%) were caused by Cryptosporidium (HLAVSA et al., 2014). In developing countries, including Brazil, there are no reports of outbreaks caused by this protozoan, probably due to the lack of surveillance and reporting.

Although the occurrence mentioned in this study is lower than those described by other authors, it is an important finding, and control measures should be taken to prevent the dissemination of this parasite. Many studies, some of them listed above, demonstrated the risk these protozoa pose to human health, and how quickly they spread in rivers, contaminating humans and animals. In order to stop this occurrence, preventive measures should be routinely determined, and special measures should be established for recreational waters.

As preventive measures, water filtration for human/animal consumption should be implemented; recreational activities in water should be avoided during a current or recent outbreak of diarrhea, recreational waters should not be used for consumption, and kids should be taken to the bathroom frequently, followed by thoroughly washing of hands before using the pool or beach, preventing autoinfection and infection of others (FAYER et al., 2000).

\section{Conclusions}

The frequency of oocysts present on beaches $(2.5 \%)$ was lower than reported in different studies worldwide using PCR. The modified Ziehl-Neelsen method was not efficient to detect the parasite. As the Cryptosporidium spp. species was not identified, it was impossible to determine the animal species responsible for the contamination of the recreational waters analyzed in this study.

\section{References}

ABRAHAMSEN, M. S.; TEMPLETON, T. J.; ENOMOTO, S.; ABRAHANTE, J. E.; ZHU, G.; LANCTO, C. A.; DENG, M.; LIU, C.; WIDMER, G.; TZIPORI, S.; BUCK, G. A.; XU, P.; BANKIER, A. T.; DEAR, P. H.; KONFORTOV, B. A.; SPRIGGS, H. F.; IYER, L.; ANANTHARAMAN, V.; ARAVIND, L.; KAPUR, V. Complete genome sequence of the apicomplexan, Cryptosporidium parvum. Science, New York, v. 304, n. 5669, p. 441-445, 2004.

ALMEIDA, J. C.; MARTINS, F. D. C.; FERREIRA NETO, J. M. F.; SANTOS, M. M.; GARCIA, J. L.; NAVARRO, I. T.; KURODA, E. K.; FREIRE, R. L. Occurrence of Cryptosporidium spp. and Giardia spp. in a public water-treatment system, Paraná, Southern Brazil. Revista Brasileira de Parasitologia Veterinária, Jaboticabal, v. 24, n. 3, p. 303-308, 2015.

ARAÚJO, R. S.; DROPA, M.; FERNANDES, L. N.; CARVALHO, T. T.; SATO, M. I.; SOARES, R. M.; MATTÉ, R. R.; MATTÉ, M. H. Genotypic characterization of Cryptosporidium hominis from water samples in Sao Paulo, Brazil. The American Journal of Tropical Medicine and Hygiene, Northbrook, v. 85, n. 5, p. 834-838, 2011.

ARROWOOD, M. J.; STERLING, C. R. Comparison of conventional staining methods and monoclonal antibodybased methods for Cryptosporidium oocyst detection. Journal of Clinical Microbiology, Washington, v. 27, n. 7, p. 1490-1495, 1989.

BANJO, T. A.; AKANO, A. M.; AMOO, A. O. J.; KAMA, A. C.; OGUNDAHUNSI, O. A.; OLOOTO, W. E.; FAMILONI, O. B.; MUTIU, W. B.; ADEBESIN, O. A.; JOHNSON, A. A.; KAMA, G. Comparative molecular and laboratory diagnostic techniques of Cryptosporidium parvum in diarrhoiec hiv positive individuals in lagos. American Journal of Research Communication, San Antonio, v. 1, n. 10, p. 97-112, 2013.

BASTOS, R. K. X.; HELLER, L.; VIEIRA, M. B. M.; BRITO, L. A.; BEVILACQUA, P. D.; NASCIMENTO, L. E. Giardia sp. cysts and Cryptosporidium spp. oocysts dynamics in southeast Brazil: occurrence in surface 
water and removal in water treatment processes. Water Science and Technology: Water Supply, Londres, v. 4, n. 2, p. 15-22, 2004.

BETANCOURT, W. Q.; DUARTE, D. C.; VÁSQUEZ, R. C.; GURIAN, P. L. Cryptosporidium and Giardia in tropical recreational marine waters contaminated with domestic sewage: Estimation of bathing-associated disease risks. Marine Pollution Bulletin, Londres, v. 85, n. 1, p. 268-273, 2014.

CARDOSO, L. S.; CARLI, G. A.; LUCA, S. J. Cryptosporidium e Giardia em efluentes biologicamente tratados e desinfetados. Engenharia Sanitaria $e$ Ambiental, Rio de Janeiro, v. 8, n. 4, p. 285-290, 2003.

CORTES, M. B. V.; BARBOSA, A. S.; SILVA, V. L.; BASTOS, O. M.; WASSERMAN, J. C. Ocorrência de parasitas patológicos nos rios Macacu, Caceribu e Guapimacacu, Rio de Janeiro, Brasil. Engevista, Rio de Janeiro, v. 16, n. 4, p. 356-366, 2014.

DURANTI, A.; CACCIÒ, S. M.; POZIO, E.; DI EGIDIO, A.; CURTIS, M. de; BATTISTI, A.; SCARAMOZZINO, P. Risk Factors Associated with Cryptosporidium parvum Infection in Cattle. Zoonoses Public Health, Berlin, v. 56, n. 4 , p. $176-182,2009$.

EL-SHAZLY, A. M.; GABR, A.; MAHMOUD, M. S.; AZIZ, S. S.; SALEH, W. A. The use of ZiehlNeelsen stain, enzyme-linked immunosorbent assay and nested polymerase chain reaction in diagnosis of cryptosporidiosis in immuno-competent, compromised patients. Journal of the Egyptian Society of Parasitology, Cairo, v. 32, n. 1, p. 155-166, 2002.

FAYER, R. Taxonomy and species delimitation in Cryptosporidium. Experimental Parasiolology, Orlando, v. 124, n. 1, p. 90-97, 2010.

FAYER, R.; MORGAN, U.; UPTON, S. J. Epidemiology of Cryptosporidium: transmission, detection and identification. International Journal of Parasitology, Oxford, v. 30, n. 12-13, p. 1305-1322, 2000.

FENG, Y. Cryptosporidium in wild placental mammals. Experimental Parasitology, Orlando, v. 124, n. 1, p. 128137, 2010.

GALVÁN, A. L.; MAGNET, A.; IZQUIERDO, F.; FERNÁNDEZ VADILLO, C.; PERALTA, R. H.; ANGULO, S.; FENOY, S.; DEL AGUILA, C. A yearlong study of Cryptosporidium species and subtypes in recreational, drinking and wastewater from the central area of Spain. The Science of the Total Environmente, Amsterdam, v. 468-469, p. 368-375, 2014.

HLAVSA, M. C.; ROBERTS, V. A.; KAHLER, A. M.; HILBORN, E. D.; WADE, T. J.; BAVCKER, L. C.; YODER, J. S. Recreational water-associated disease outbreaks - United States, 2009-2010. Centers for Disease Control and Prevention, Atlanta, v. 63, n. 1, p. 6-10, 2014.

HOPKINS, J.; HAGUE, H.; HUDGIN, G.; ROSS, L.; MOORE, D. An outbreak of Cryptosporidium at a recreational water park in Niagara Region, Canada. Journal of Environmental Health, Denver, v. 75, n. 9, p. 28-33, 2013.

JÚLIO, C.; SÁ, C.; FERREIRA, I.; MARTINS, S.; OLEASTRO, M.; ANGELO, H.; GUERREIRO, J.; TENREIRO, R. Waterborne transmission of Giardia and Cryptosporidium at river beaches in Southern Europe (Portugal). Journal of Water and Health, Londres, v. 10, n. 3, p. 484-496, 2012.

KAR, S.; GAWLOWSKA, S.; DAUGSCHIES, A.; BANGOURA, B. Quantitative comparison of different purification and detection methods for Cryptosporidium parvum oocysts. Veterinary Parasitology, Amsterdam, v. 177, n. 3-4, p. 366-370, 2011.

LALLO, M. A.; BONDAN, E. F. Prevalência de Cryptosporidium sp. em cães de instituições da cidade de São Paulo. Revista de Saúde Pública, São Paulo, v. 40, n. 1, p. 120-125, 2006.

LOGANTHAN, S.; YANG, R.; BATH, A.; GORDON, C.; RYAN, U. Prevalence of Cryptosporidium species in recreational versus non recreational water sources. Experimental Parasitology, Orlando, v. 131, n. 4, p. 399403, 2012.

MACHADO, E. C. L.; STAMFORD, T. L. M.; ALVES, L. C.; MELO, R. G.; SHINOHARA, N. K. S. Effectiveness of Cryptosporidium spp. oocysts detection and enumeration methods in water and milk samples. Arquivo Brasileiro de Medicina Veterinária e Zootecnia, Belo Horizonte, v. 58, n. 3, p. 432-439, 2006.

MANOUCHEHRI NAEINI, K.; ASADI, M.; HASHEMZADE, C. M. Detection and molecular characterization of Cryptosporidium species in recreational waters of chaharmahal va bakhtiyari province of Iran using nested-PCR-RFLP. Iran Journal of Parasitology, Tehran, v. 6, n. 1, p. 20-27, 2011.

MASOOD, S.; MAQBOL, A.; ANJUM, A.; RASHID, M. I.; CHOUDHARY, Z. I. Prevalence of Cryptosporidium oocysts in bovine at different livestock farms by conventional microscopic and molecular techniques. Journal of Animal and Plant Sciences, Lahore, v. 23, n. 6, p. 1580-1594, 2013.

MORGAN, U. M.; PALLANT, L.; DWYER, B. W.; FORBES, D. A.; RICH, G.; THOMPSON, R. C. A. Comparison of PCR and microscopy for detection of Cryptosporidium parvum in human fecal specimens: 
clinical trial. Journal of Clinical Microbiology, Washington, v. 36, n. 4, p. 995-998, 1998.

ORTOLANI, E. L. Standardization of the modified ZiehlNeelsen technique to stain oocysts of Cryptosporidium sp. Revista Brasileira de Parasitologia Veterinária, Belo Horizonte, v. 9, n. 1, p. 29-31, 2000.

OSAKI, S. C.; SOCCOL, V. T.; COSTA, A. O.; OLIVEIRA-SILVA, M. B.; PEREIRA, J. P.; PROCÓPIO, A. E. Polymerase chain reaction and nested-PCR approaches for detecting Cryptosporidium in water catchments of water treatment plants in Curitiba, State of Paraná, Brazil. Revista da Sociedade Brasileira de Medicina Tropical, Rio de Janeiro, v. 46, n. 3, p. 270276, 2013.

PAUL, S.; CHANDRAA, D.; TEWARIA, A. K.; BANERJEEA, P. S.; RAYA, D. D.; BORALB, R.; RAOA, J. R. Comparative evaluation and economic assessment of coprological diagnostic methods and PCR for detection of Cryptosporidium spp. in bovines. Veterinary Parasitology, Amsterdam, v. 164, n. 2-4, p. 291-295, 2009.

PEREIRA, M. G. C.; LI, X.; MCCOWAN, B.; PHILLIPS, R. L.; ATWILL, E. R. Multiple unique Cryptosporidium isolates from three species of ground squirrels $(S$. permophilus beecheyi, S. beldingiand, S. lateralis) in California. Applied and Environmental Microbiology, Washington, v. 76, n. 24, p. 8269-8276, 2010.

PLUTZER, J.; KARANIS, P.; DOMOKOS, K.; TÖRÖKNÉ, A.; MÁRIALIGETI, K. Detection and characterisation of Giardia and Cryptosporidium in Hungarian raw, surface and sewage water samples by IFT, PCR and sequence analysis of the SSUrRNA and GDH genes. International Journal of Hygiene and Environmental Health, Jena, v. 211, n. 5-6, p. 524-533, 2008.

RYAN, U.; FAYER, R.; XIAO, L. Cryptosporidium species in humans and animals: current understanding and research needs. Parasitology, Londres, v. 141, n. 13, p. 1667-1685, 2014.

SANTÍN, M. Clinical and subclinical infections with Cryptosporidium in animals. New Zealand Veterinary Journal, Abington, v. 61, n. 1, p. 1-10, 2013.
SANTOS, L. U.; BONATTI, T. R.; CANTUSIO NETO, R.; FRANCO, R. M. B. Occurrence of Giardia cysts and Cryptosporidium oocysts in activated sludge samples in Campinas, SP, Brazil. Revista do Instituto de Medicina Tropical de São Paulo, São Paulo, v. 46, n. 6, p. 309-313, 2004.

SAVIOLI, L.; SMITH, H.; THOMPSON, A. Giardia and Cryptosporidium join the neglected diseases initiative. Trends in Parasitology, Oxford, v. 22, n. 5, p. 203-208, 2006.

SHI, K.; JIAN, F. L. V. C.; NING, C.; ZHANG, L.; REN, X.; DEAREN, T. K.; LI, N.; QI, M.; XIAO, L. Prevalence, genetic characteristics, and zoonotic potential of Cryptosporidium species causing infections in farm rabbits in China. Journal of Clinical Microbiology, Washington, v. 48, n. 9, p. 3263-3266, 2010.

TAHVILDAR-BIDEROUNI, F.; SALEHI, N. Detection of Cryptosporidium infection by modified ziehl-neelsen and PCR methods in children with diarrheal samples in pediatric hospitals in Tehran. Gastroenterology and Hepatology from Bed to Bench, Tehran, v. 7, n. 2, p. 125130, 2014.

WALDRON， L. S.; CHEUNG-KWOK-SANG， C.; POWER, M. L. Wildlife-associated Cryptosporidium fayeri in human, Australia. Emerging Infectious Disease, Atlanta, v. 16, n. 12, p. 2006-2007, 2010.

XIAO, L.; ESCALANTE, L.; YANG, C.; SULAIMAN, I.; ESCALANTE, A. A.; MONTALI, R. J.; FAYER, R.; LAL, A. A. Phylogenetic analysis of Cryptosporidium parasites based on the small-subunit rRNA gene locus. Applied and Environmental Microbiology, Washington, v. 65 , n. 4 , p. $1578-1583,1999$.

XIAO, G.; WANG, Z.; CHEN, J.; QIU, Z.; LI, Y.; QI, J.; LIU, W.; SHU, W. Occurrence and infection risk of waterborne pathogens in Wanzhou watershed of the three Gorges Reservoir, China. Journal of Environmental Scinces, Amsterdam, v. 25, n. 9, p. 1913-1924, 2013.

XIAO, L.; FAYER, R.; RYAN, U.; STEVE, J. Cryptosporidium taxonomy: recent advances and implications for public health. Clinical Microbiology Reviews, Atlanta, v. 17, n. 1, p. 72-97, 2004.

XIAO, L.; RYAN, U. Cryptosporidiosis: na update in molecular epidemiology. Current Opinion in Infections Diseases, Londres, v. 17, n. 5, p. 483-490, 2004. 
